\title{
Effect of Sex Hormones on Bone
}

\section{in Primary Osteoporosis}

\author{
B. Lawrence Riggs, Jenifer Jowsey, Patrick J. Kelly, James D. Jones, \\ and Frank T. MAhER \\ From the Mayo Clinic and Mayo Foundation, Sections of Medicine, Surgical \\ Research, Orthopedic Surgery, Biochemistry, and Clinical Pathology, \\ Rochester, Minnesota 55901
}

\begin{abstract}
A B S TRACT The effect of sex hormones on bone tissue was studied in 12 osteoporotic patients. Surfaces of bone undergoing formation and resorption were determined by quantitative microradiography of iliac crest biopsy samples before and after treatment with estrogens in 11 postmenopausal women and with testosterone in one gonadally competent man. Before treatment, bone resorption was greater than normal in all but one patient and bone formation was normal. After treatment, bone resorption decreased to within the normal range in all patients, and bone formation did not change significantly. Biochemical studies showed significant decreases in serum calcium, phosphorus, and alkaline phosphatase levels and in urinary excretion of calcium and hydroxyproline. These changes are believed to be the consequence of the effect of the hormones on bone. The data indicate that the major effect of sex hormones in osteoporosis is an inhibition of bone resorption.
\end{abstract}

\section{INTRODUCTION}

Albright, Smith, and Richardson in 1941 proposed that anabolic sex hormones were necessary for bone matrix synthesis, and that the loss of estrogens at the menopause in women or of androgens with aging in men caused osteoporosis (1). Since then, sex hormones have been used extensively in the treatment of osteoporosis, although their mechanism of action and therapeutic usefulness have not been completely established.

Estrogens stimulate intramedullary bone formation in birds (2), but their effect on mammalian bone is variable. Experiments have demonstrated increased endosteal formation in mice (3), decreased endosteal resorption in rats (4), and no specific skeletal response in

Received for publication 27 November 1968. kittens or in puppies (5). Also, if a defect in matrix synthesis is to be postulated, it is difficult to explain why neither castration nor protein restriction produces osteoporosis in experimental animals, although it can readily be produced by calcium deficiency $(6,7)$, immobilization (8), or corticosteroid administration (9).

Studies of bone turnover have shown that the major cause of decreased bone mass in human osteoporosis is not the decrease in bone formation predicted by Albright et al. (1) but rather an increase in bone destruction. Quantitative microradiographic studies, by Jowsey et al. (10), of bone biopsy samples from osteoporotic patients have shown that bone-forming surfaces generally are normal, and that bone-resorbing surfaces are increased by a factor of two to four. Tetracycline-labeling studies showed that bone formation rates in ribs of osteoporotic patients do not differ significantly from those in normal persons (11). By estimating the rate of resorption in the rib from knowledge of the bone formation rate and the rib porosity, $\mathrm{Wu}$, Jett, and Frost (12) found an absolute increase in endosteal resorption rate (the process accounting for most of the resorption in the vertebrae), although the intracortical resorption rate was found to be lower than normal. Studies with bone-seeking isotopes have shown that skeletal mineral accretion is normal or is decreased in proportion to the decreased skeletal mass (13-17).

Some authors have suggested that the association of osteoporosis with the menopause is largely fortuitous because autopsy studies have conclusively demonstrated that maximal bone mass is attained between ages 20 and $40 \mathrm{yr}$ in both sexes, and then there is a progressive bone atrophy which begins premenopausally in women and correlates linearly with age (18-20). Clinical and in vivo densitometric studies have given conflicting results, some showing $(21,22)$ and others failing to 
show (23-25) an effect of the menopause independent of age.

Although treatment with sex hormones produces calcium retention in the majority of osteoporotic patients studied by metabolic balance methods (26), the failure of bone to increase in radiodensity even after years of treatment suggests that the short-term calcium retention cannot be maintained indefinitely (26). Also, Solomon, Dickerson, and Eisenberg (27) have shown that the relief of symptoms with estrogens is largely a placebo effect. However, treatment with sex hormones has been reported to arrest further height loss in osteoporotic patients (26). Also, postmenopausal or castrated women who had received estrogen replacement therapy have been shown to have a higher bone density of the appendicular skeleton when assessed by in vivo densitometric techniques, compared with similar women who did not receive hormones $(28,29)$.

Because of the conflicting results obtained in these previous studies, we examined directly the effect of sex hormones on bone tissue by using quantitative microradiography of bone biopsy samples. Alterations of certain biochemical parameters, which occurred as a result of hormone treatment, were also studied.

\section{METHODS}

Patients. Twelve ambulatory patients with progressive osteoporosis of sufficient severity to produce vertebral deform- ity were studied. None of the patients had any evident medical disease other than osteoporosis. Pertinent clinical features are given in Table I. Except for two patients (Nos. 8 and 9) who had discontinued therapy 10 months and $4 \mathrm{yr}$, respectively, before this study, none had had previous treatment. All patients underwent iliac crest bone biopsy for microradiographic studies of bone remodeling before and after administration of a sex steroid. In nine of the patients (Nos. 1-9), all postmenopausal, additional metabolic studies were performed before and after 10-16 wk of cyclic administration of conjugated equine estrogens (Premarin), 2.5 $\mathrm{mg} /$ day. Three patients (Nos. 10-12) had bone biopsies but no metabolic studies; these were two postmenopausal women who received cyclic therapy with conjugated estrogens in a dose of $2.5 \mathrm{mg} /$ day for 4 months and $1.25 \mathrm{mg} /$ day for 18 months, respectively, and a $48 \mathrm{yr}$ old gonadally competent man who received $400 \mathrm{mg}$ of testosterone ethanate (Deletestryl) intramuscularly once a month for $\mathbf{1 2}$ months. During the interval before restudy the patients were maintained on their usual diet and had no other form of therapy.

Microradiography. Samples of anterior iliac crest bone from seven patients and of posterior iliac crest bone from five patients were obtained for quantitative microradiography. Two sections were studied from each sample. This method as developed by Jowsey et al. (10) provides a numerical evaluation of the amounts of resorption and formation taking place in a piece of bone tissue. Active sites of bone formation and resorption are identified in a microradiograph of a calcified bone section. Bone resorption produces an uneven, crenated surface of high mineral density, which has been correlated with the presence of osteoclasts. Areas of bone formation are of low mineral density with a smooth surface not bounded by a sclerotic line; this appearance has been correlated with the presence of osteoblasts, with a

TABLE I

Summary of Relevant Clinical Data

\begin{tabular}{|c|c|c|c|c|c|c|c|}
\hline Patient & Age, sex & $\begin{array}{l}\text { No. of } \\
\text { crush } \\
\text { fractures } \\
\text { on spinal } \\
\text { roentgen- } \\
\text { ograms }\end{array}$ & $\begin{array}{c}\text { Interval } \\
\text { since last } \\
\text { acute back } \\
\text { pain }\end{array}$ & $\begin{array}{c}\text { Age at } \\
\text { menopause }\end{array}$ & $\begin{array}{l}\text { Home dietary } \\
\mathrm{Ca} \text { intake }\end{array}$ & $\begin{array}{c}\text { Duration of } \\
\text { treatment } \\
\text { before restudy }\end{array}$ & $\begin{array}{l}\text { Site of } \\
\text { biopsy* }\end{array}$ \\
\hline & & & month & $y r$ & $m g / d a y$ & month & \\
\hline 1 & $60 \mathrm{~F}$ & 1 & 2 & 43 & 440 & 3 & PIC \\
\hline 2 & $57 \mathrm{~F}$ & 1 & 8 & 52 & 1200 & 3 & PIC \\
\hline 3 & $61 \mathrm{~F}$ & 1 & 1 & $42 \ddagger$ & 1300 & 3 & AIC \\
\hline 4 & $63 \mathrm{~F}$ & 4 & 4 & 48 & 695 & 4 & AIC \\
\hline 5 & $55 \mathrm{~F}$ & 2 & 22 & $41 \ddagger$ & 440 & 4 & AIC \\
\hline 6 & $63 \mathrm{~F}$ & 3 & 4 & 50 & 500 & 4 & AIC \\
\hline 7 & $67 \mathrm{~F}$ & 2 & 6 & $48 \ddagger$ & 400 & 4 & AIC \\
\hline $8 \S$ & $62 \mathrm{~F}$ & 2 & 12 & $42 \ddagger$ & 350 & 3 & AIC \\
\hline 9|| & $60 \mathrm{~F}$ & 7 & T & 39 & 850 & $2 \frac{1}{2}$ & AIC \\
\hline 10 & $43 \mathrm{~F}$ & 1 & $\frac{1}{2}$ & $39 \ddagger$ & 900 & 4 & PIC \\
\hline 11 & $67 \mathrm{~F}$ & 5 & 6 & 54 & 500 & 18 & PIC \\
\hline 12 & $48 \mathrm{M}$ & 1 & $* *$ & - & 600 & 12 & PIC \\
\hline
\end{tabular}

* AIC, anterior iliac crest; PIC, posterior iliac crest.

¥ Surgical menopause.

\$ Previous treatment, estrogens for 2 months; stopped 10 months_before this study.

|| Previous treatment, estrogens for $3 \mathrm{yr}$; stopped $4 \mathrm{yr}$ before this study.

I No acute pain; chronic backache for $5 \mathrm{yr}$.

** No acute pain; chronic backache for $3 \mathrm{yr}$. 
border of osteoid tissue, and with surface of bone that accumulates tetracycline. (Tetracycline deposition has been shown to be associated with the calcification of collagen [30].) The lengths of surfaces undergoing resorption and formation are measured on an enlarged photomicrograph and expressed quantitatively as percentages of total surface in the section. These values, therefore, refer to the amount of surface involved by the two aspects of bone turnover: bone resorption and bone formation. The values differ in different sites within the same skeleton but bear a relatively constant ratio to each other. To equate surface measurements with rates of bone formation and resorption it is necessary to make the reasonable but unproven assumption that the rate of bone deposition or destruction per unit length of active surface is relatively constant. By use of tetracycline labeling it has been shown that the appositional rate of bone formation is about $1 \mu /$ day in a group of patients with a variety of medical diseases (31). The theoretical justification for the technique has been reviewed $(10,32)$.

Biochemical studies. The patients were hospitalized in a metabolic ward and ate a daily diet containing $650 \mathrm{mg}$ of calcium, $900 \mathrm{mg}$ of phosphorus, and $125 \mathrm{~g}$ of lean meat but no candy or gelatin. For each patient, serum calcium, phosphorus, and alkaline phosphatase were determined two to four times, and the serum proteins were studied by paper electrophoresis once. The 24-hr urinary excretions of calcium and hydroxyproline were determined on 3 successive days. On the 4th day, renal clearance studies were performed at 8 a.m. while the patient was fasting and hydrated.

The serum calcium was determined by semiautomated complexometric titration (33) (normal, 8.9-10.1 mg/100 $\mathrm{ml})$; phosphorus as inorganic phosphates by the method of
Frings, Rahman, and Jones (34) (normal, 2.5-4.5 mg/100 $\mathrm{ml}$ ) ; and serum alkaline phosphatase by the method of Marsh, Fingerhut, and Kirsch (35) (normal, $<60 \mathrm{U} /$ liter). Urinary calcium was determined by the method of Yarbro and Golby (36) and urinary hydroxyproline, by the method of Prockop and Udenfriend (37). The glomerular filtration rate was determined by inulin clearance (38), and the tubular reabsorption of phosphate (TRP) was determined from the formula :

$$
\% \mathrm{TRP}=\left(1-\mathrm{C}_{\mathrm{PO}_{4}} / \mathrm{C}_{\text {1nu11n }}\right) \times 100 \text {. }
$$

Serum gonadotropins were determined by radioimmunoassay $(39,40)$, and results were expressed as micrograms of LER 907 standard per $100 \mathrm{ml}$ of serum (41). Excluding values on the day of ovulation, for normal premenopausal women the mean is 17.5 (range, 12.5-95) for folliclestimulating hormone (FSH) and 16.4 (range, 8.4-27.7) for luteinizing hormone (LH).

\section{RESULTS}

Microradiography. The data from the osteoporotic patients were compared with merged data from 23 persons without metabolic disease, matched as to age, sex, and biopsy site. For this normal group the mean, $1 \mathrm{SD}$, and range were: bone resorption, $5.27 \pm 2.43 \%$, $1.34-11.0 \%$; bone formation, $4.30 \pm 2.56 \%, 1.02-8.81 \%$. For a group of 15 normal premenopausal women, ages $20-45 \mathrm{yr}$, the values were: bone resorption, 4.91

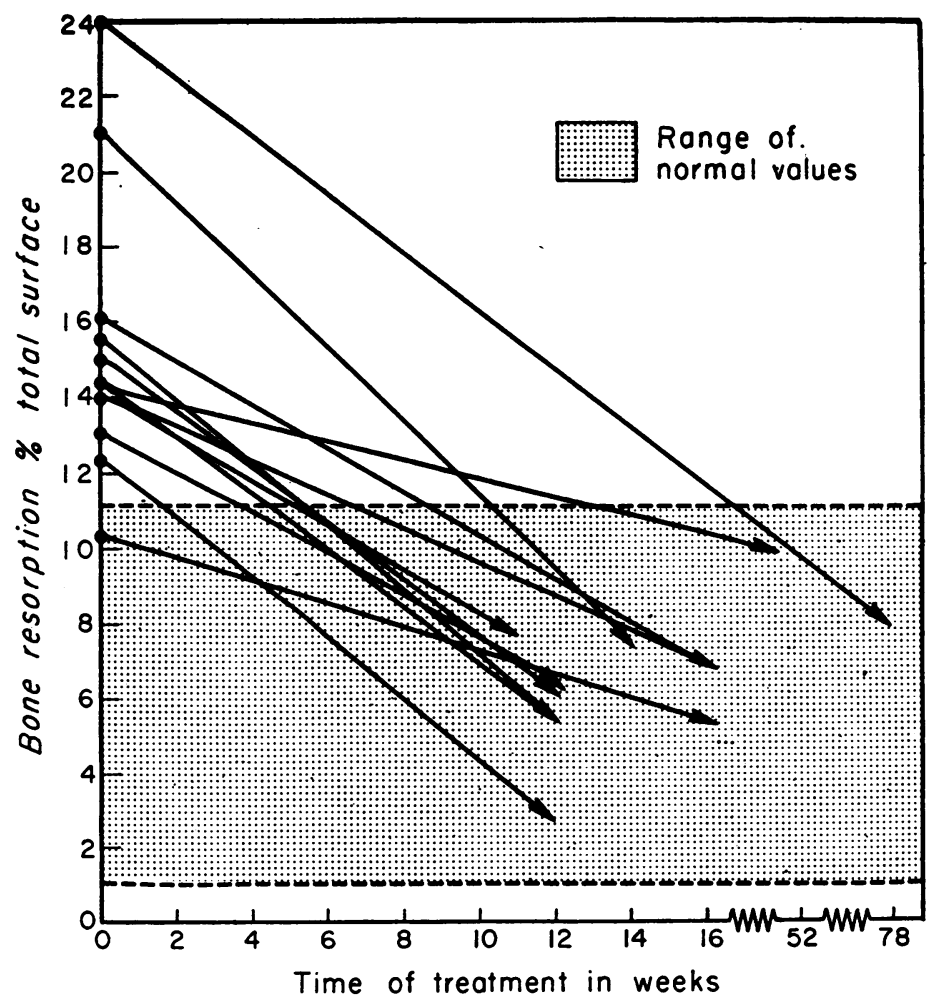

FIGURE 1 Effect of sex hormone on bone resorption. 
TABLE II

Effect of Sex Hormones on Some

\begin{tabular}{|c|c|c|c|c|c|c|c|c|c|c|}
\hline \multirow[b]{2}{*}{$\begin{array}{c}\mathrm{Pa}- \\
\text { tient }\end{array}$} & \multicolumn{2}{|c|}{ Bone resorption } & \multicolumn{2}{|c|}{ Bone formation } & \multicolumn{2}{|c|}{ Serum Ca } & \multicolumn{2}{|c|}{ Serum $\mathbf{P}$} & \multicolumn{2}{|c|}{ Alk. phosphatase } \\
\hline & $\begin{array}{l}\text { Be- } \\
\text { fore }\end{array}$ & After & $\begin{array}{l}\text { Be- } \\
\text { fore }\end{array}$ & After & $\begin{array}{l}\text { Be- } \\
\text { fore }\end{array}$ & After & $\begin{array}{l}\mathrm{Be}- \\
\text { fore }\end{array}$ & After & $\begin{array}{l}\text { Be- } \\
\text { fore }\end{array}$ & After \\
\hline & \multicolumn{2}{|c|}{$\%$} & \multicolumn{2}{|c|}{$\%$} & \multicolumn{2}{|c|}{$m g / 100 m l$} & \multicolumn{2}{|c|}{$m g / 100 m l$} & \multicolumn{2}{|c|}{$U /$ liter } \\
\hline 1 & 14.3 & 5.3 & 3.2 & 7.1 & 9.93 & 8.90 & 4.10 & 2.80 & 60 & 45 \\
\hline 2 & 14.0 & 7.7 & 5.1 & 3.1 & 9.30 & 9.05 & 3.57 & 3.25 & 38 & - \\
\hline 3 & 12.3 & 2.7 & 5.1 & 3.7 & 9.85 & 8.80 & 3.43 & 2.90 & 62 & 39 \\
\hline 4 & 14.0 & 6.8 & 4.4 & 2.2 & 9.90 & 9.30 & 3.51 & 2.90 & 101 & 34 \\
\hline 5 & 21.0 & 7.4 & 6.3 & 2.2 & 9.40 & 9.20 & 3.35 & 2.60 & 65 & 44 \\
\hline 6 & 15.5 & 5.3 & 5.3 & 5.3 & 9.70 & 9.45 & 3.16 & 2.70 & 24 & 18 \\
\hline 7 & 13.0 & 6.4 & 3.6 & 3.3 & 10.40 & 9.50 & 3.10 & 3.02 & 46 & 29 \\
\hline 8 & 15.0 & 6.1 & 5.3 & 1.8 & 9.36 & 9.30 & 3.43 & 2.83 & 38 & 36 \\
\hline 9 & 16.0 & 10.3 & 4.8 & 7.7 & 9.60 & 9.50 & 3.50 & 3.10 & 41 & 34 \\
\hline 10 & 10.4 & 5.4 & 4.2 & 5.7 & & & & & & \\
\hline 11. & 24.0 & 7.8 & 1.1 & 0.7 & & & & & & \\
\hline 12 & 14.2 & 9.7 & 3.9 & 0.2 & & & & & & \\
\hline Mean & 15.3 & 6.7 & 4.4 & 3.6 & 9.72 & 9.22 & 3.46 & 2.90 & 52.7 & 34.9 \\
\hline$\pm \mathrm{SE}$ & \pm 1.1 & \pm 0.6 & \pm 0.4 & \pm 0.7 & \pm 0.12 & \pm 0.09 & \pm 0.10 & \pm 0.07 & \pm 7.5 & \pm 2.8 \\
\hline$P$ & \multicolumn{2}{|c|}{$<0.001$} & \multicolumn{2}{|c|}{ NS } & \multicolumn{2}{|c|}{$<0.01$} & \multicolumn{2}{|c|}{$<0.005$} & \multicolumn{2}{|c|}{$<0.05$} \\
\hline
\end{tabular}

$\pm 2.29 \%, 1.10-8.90 \%$; bone formation, $2.43 \pm 1.40 \%$, $1.00-6.00 \%$. Since bone remodeling varies somewhat between the anterior and posterior iliac crest and with age and sex, the standard deviations and ranges are wider than those previously reported for unmerged data.

Before treatment, bone resorption was higher than the normal range in all but one of the osteoporotic patients. After treatment for $2 \frac{1}{2}-4$ months in 10 patients and $1-1 \frac{1}{2} \mathrm{yr}$ in two patients, the individual bone resorption values were within the normal range in all 12 patients. Among the 11 postmenopausal women, the values after

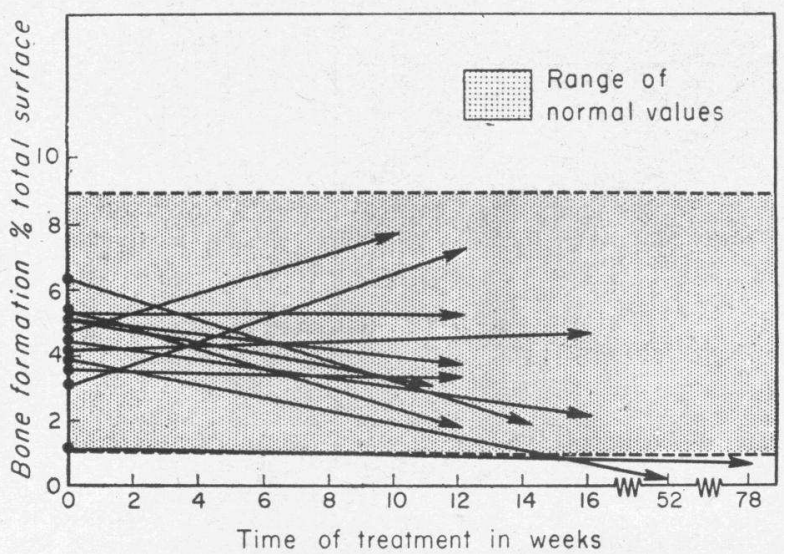

Figure 2 Effect of sex hormone on bone formation. treatment were within the premenopausal range in all but two. The difference in bone resorption between the pretreatment (mean $\pm \mathrm{SE}, 15.3 \pm 1.1 \%$ ) and posttreatment $(6.7 \pm 0.6 \%)$ values of the patient group was highly significant $(P<0.001)$. There was no demonstrable relationship between the duration of treatment and the degree of response.

Bone formation was normal in all patients before treatment (mean $\pm \mathrm{SE}, 4.4 \pm 0.4 \%$ ) and did not change significantly after treatment $(3.6 \pm 0.7 \%)$. However, low values for formation $(0.7$ and $0.2 \%)$ were found in the two patients treated for more than $1 \mathrm{yr}$ although, in one of these, formation was initially in the low normal range. The individual data are shown in Table II and illustrated in Figs. 1 and 2.

Biochemical studies. In the nine patients undergoing metabolic studies, small but significant decreases occurred in serum calcium, phosphate, and alkaline phosphatase levels and in urinary excretion of calcium and hydroxyproline. Almost all of these changes occurred within the normal ranges. There was no significant change in the serum total protein concentration or in TRP. Before treatment, the serum gonadotropins were in the high or high normal range. After estrogen therapy, decreases occurred in all patients, generally to within the normal range, and only one individual had less-than-normal gonadotropin levels. The results of the biochemical studies are shown in Table II. 
Metabolic Parameters in Osteoporosis

\begin{tabular}{|c|c|c|c|c|c|c|c|c|c|c|c|}
\hline \multicolumn{2}{|c|}{ Urinary $\mathrm{Ca}$} & \multicolumn{2}{|c|}{$\begin{array}{c}\text { Urinary } \\
\text { hydroxyproline }\end{array}$} & \multicolumn{2}{|c|}{ TRP } & \multicolumn{2}{|c|}{ Total serum protein } & \multicolumn{2}{|c|}{ Serum FSH* } & \multicolumn{2}{|c|}{ Serum LH* } \\
\hline $\begin{array}{l}\text { Be- } \\
\text { fore }\end{array}$ & After & $\begin{array}{l}\text { Be- } \\
\text { fore }\end{array}$ & After & $\begin{array}{l}\text { Be- } \\
\text { fore }\end{array}$ & After & $\begin{array}{l}\text { Be- } \\
\text { fore }\end{array}$ & After & $\begin{array}{l}\text { Be- } \\
\text { fore }\end{array}$ & After & $\begin{array}{l}\text { Be- } \\
\text { fore }\end{array}$ & After \\
\hline \multicolumn{2}{|c|}{$m g / 24 h r$} & \multicolumn{2}{|c|}{$m g / 24 h r$} & \multicolumn{2}{|c|}{$\%$} & \multicolumn{2}{|c|}{$\mathrm{g} / 100 \mathrm{ml}$} & & & & \\
\hline 138 & 45 & 16.7 & 9.1 & 86 & 88 & 6.09 & 7.03 & 56 & 38 & 64 & 13 \\
\hline 71 & 69 & 29.1 & 15.2 & 83 & 68 & 6.24 & 6.30 & - & 85 & 85 & 55 \\
\hline 170 & 97 & 31.4 & 14.8 & 81 & 80 & 5.84 & 6.82 & 120 & $<10$ & 32 & 15 \\
\hline 173 & 36 & 29.6 & 28.1 & 79 & 82 & 6.03 & 6.20 & 103 & 40 & 20 & 15 \\
\hline 284 & 173 & 29.6 & 28.1 & 78 & 79 & 7.01 & 6.79 & 115 & 49 & 57 & 16 \\
\hline 123 & 61 & 25.7 & 18.4 & 76 & 80 & 6.18 & 5.90 & 60 & 15 & 12 & 9 \\
\hline 110 & 74 & 23.0 & 20.5 & 78 & 80 & 6.82 & 5.77 & 一 & 59 & 58 & 31 \\
\hline 111 & 79 & 19.3 & 18.3 & 78 & 72 & 6.35 & 6.26 & 250 & 48 & 58 & 21 \\
\hline 122 & 97 & 25.3 & 26.3 & 87 & 75 & 5.71 & 5.75 & 100 & 15 & 26 & 8 \\
\hline 144.7 & 81.2 & 25.5 & 19.9 & 80.7 & 78.3 & 6.25 & 6.31 & & & & \\
\hline \pm 20.3 & \pm 13.4 & \pm 1.7 & \pm 2.2 & \pm 1.3 & \pm 1.9 & \pm 0.15 & \pm 0.17 & & & & \\
\hline \multicolumn{2}{|c|}{$<0.005$} & \multicolumn{2}{|c|}{$<0.05$} & \multicolumn{2}{|c|}{ NS } & \multicolumn{2}{|c|}{ NS } & & & & \\
\hline
\end{tabular}

TRP, tubular reabsorption of phosphate; FSH, follicle-stimulating hormone; LH, luteinizing hormone.

* As micrograms of LER 907 standard per $100 \mathrm{ml}$.

\section{DISCUSSION}

The treatment period of $2 \frac{1}{2}-4$ months was believed to be long enough for estrogen to produce an effect on bone metabolism. Previous metabolic balance studies have shown that calcium retention may occur during the 1st wk of estrogen therapy and may become progressively more prominent for at least 30 days (42). The time of treatment was also short enough to ensure that any effects could be clearly attributed to treatment. Our patients were randomly selected, and the time interval since the last acute episode of back pain (and presumably the last vertebral compression) ranged from $2 \mathrm{wk}$ to 22 months. Since it is highly unlikely that bone resorption would decrease to within the normal range spontaneously in all 10 patients in the short-term treatment group, we believe that the observed changes were the result of estrogen therapy.

Our data show that the major effect of sex hormones on osteoporosis is an inhibition of bone resorption. This has been proposed by investigators (43-45) who failed to observe the increase in the rate of skeletal isotope accretion predicted by traditional theory. Lafferty, Spencer, and Pearson (44) also noted that sex hormone therapy altered the break in the serum ${ }^{47} \mathrm{Ca}$ specific activity time curve and thought that this change quantitatively reflected inhibition of bone resorption. However, there are reasons for doubting the validity of this type of analysis (46). It is not clear from our data whether the inhibition of bone resorption is a direct effect of the hormones on bone or is a consequence of altered responsiveness of bone to endogenous parathyroid hormone, as has been suggested by Heaney (47) and by Jasani, Nordin, Smith, and Swanson (48).

We found no change in amount of bone surfaces undergoing formation. In studies of osteoporotic patients receiving androgens or estrogens for less than 3 months, Lafferty et al. (44) found the skeletal ${ }^{47} \mathrm{Ca} \mathrm{ac}$ cretion to be unchanged. However, Eisenberg (45) found a $10 \%$ reduction in the rate of skeletal accretion of strontium in osteoporotic patients receiving estrogens for 5-6 wk. Because skeletal accretion of boneseeking isotopes is the sum of several processes, only one of which is the mineralization of collagen (49), it is possible that the reduction in accretion noted by Eisenberg was nonspecific and was related to an overall reduction in mineral turnover. It is also possible that a reduction in rate of bone formation occurred which was not reflected in a proportional decrease in surface lengths. On the other hand, Lafferty et al. (44) found a reduction of ${ }^{47} \mathrm{Ca}$ accretion in three of four osteoporotic patients receiving sex hormones for more than 9 months. This reduced accretion was accompanied by a diminution of calcium retention as judged by metabolic balance. Similarly, our two patients who had received hormones for at least $1 \mathrm{yr}$ before rebiopsy also had very low values for bone formation. A sustained in- 
hibition of bone resorption with a secondary decrease in bone formation would provide a basis for the commonly held belief that treatment with sex hormones can arrest but cannot cure osteoporosis. It also would explain the apparent inability to maintain a positive calcium balance throughout long periods of treatment.

Coincident with the inhibition of bone resorption, significant reductions also occurred in the serum calcium, phosphate, and alkaline phosphatase levels and in the urinary excretion of calcium and hydroxyproline. Reductions in serum calcium $(50,51)$, phosphorus $(42$, 50-52), and alkaline phosphatase (44) have been observed by previous investigators. Reduction in urinary calcium excretion has been an almost constant occurrence in osteoporotic patients when sex hormones have produced positive calcium balances (42). Young, Jansani, Smith, and Nordin (51) failed to find a significant decrease in urinary hydroxyproline in osteoporotic patients treated for 5 days with small doses of estrogens, but Katz and Kappas (53) found a significant reduction in 11 of 13 patients with resorptive bone diseases who were receiving pharmacologic doses of estrogens. It is noteworthy that Young and Nordin (54) found that the plasma and urinary calcium and phosphorus and urinary hydroxyproline values tend to increase in women after menopause.

We think that all of the observed biochemical effects can be adequately explained by the direct effect of sex hormones on bone tissue. Nassim, Saville, and Mulligan (52) thought that the reduction in serum phosphorus after estrogen administration was entirely a renal effect because renal tubular maximum for phosphate decreased in all of their five patients treated with stilbestrol for 2-3 wk. However, Young et al. (51) found no change in the phosphorus excretion index in 15 osteoporotic patients during 5 days of ethinyl estradiol administration, and Gardner et al. (55) found no change in the tubular reabsorption of phosphorus in cancer patients receiving pharmacologic doses of androgens. Our renal phosphate excretion data agree with those of the latter workers. We also agree with Jasani et al. (48) that it is unlikely that the major cause of the estrogeninduced reduction in urinary calcium excretion is increased tubular reabsorption of calcium. This mechanism would result in an increase in the serum calcium level but, in fact, a decrease was observed.

The decrease in serum phosphatase level is paradoxic because this enzyme is usually considered to reflect only osteoblastic activity. However, total bone turnover may contribute to the serum alkaline phosphatase activity because Kroon (56) found increased skeletal alkaline phosphatase activity after the acute administration of parathyroid extract, at a time when the osteoblasts had been replaced with fibroblasts and osteoclasts. If urinary hydroxyproline excretion reflects the breakdown of skeletal collagen (57), the reduction seen after treatment may be a measure of a decrease in bone resorption. However, this parameter is nonspecific (57) and may reflect other effects of estrogen as well, such as a stimulation of synthesis of extraosseous collagen.

Because increased bone resorption appears to be the major cause of bone loss in osteoporosis, the finding that a substantial reduction in bone resorption occurs when approximately physiologic replacement doses (assessed by the effect on serum gonadotropins) of estrogens are administered to women with postmenopausal osteoporosis supports the theory that the menopause may be a contributing factor in pathogenesis. However, the favorable short-term response to sex hormones noted in this study does not necessarily mean that bone resorption can be inhibited indefinitely by sex hormone treatment, nor does it exclude the etiologic importance of other factors known to influence bone resorption.

\section{ACKNOWLEDGMENTS}

We are grateful to Dr. R. J. Ryan for performing the radioimmunoassays for gonadotropins in these patients.

This investigation was supported in part by research grant AM-8658 from the National Institutes of Health, U. S. Public Health Service.

\section{REFERENCES}

1. Albright; F., P. H. Smith, and A. M. Richardson. 1941. Postmenopausal osteoporosis: its clinical features. $J$. Amer. Med. Ass. 116: 2465 .

2. Pfeiffer, C. A., and W. U. Gardner. 1938. Skeletal changes and blood serum calcium level in pigeons receiving estrogens. Endocrinology. 23: 485.

3. Silberberg, M., and R. Silberberg. 1941. The difference in the response of skeletal tissues to estrogen in mice of various ages. Anat. Rec. 80: 347.

4. Lindquist, B., A. M. Budy, F. C. McLean, and J. L. Howard. 1960. Skeletal metabolism in estrogen-treated rats studied by means of $\mathrm{Ca}^{45}$. Endocrinology. 66: 100 .

5. McLean, F. C., and M. R. Urist. 1961. Bone: An Introduction to the Physiology of Skeletal Tissue. University of Chicago Press, Chicago. 2nd edition. 109.

6. Harrison, M., and R. Fraser. 1960. The parathyroid glands and calcium deficiency in the rat. $J$. Endocrinol. 21: 207.

7. Jowsey, J., and J. Gershon-Cohen. 1964. Effect of dietary calcium levels on production and reversal of experimental osteoporosis in cats. Proc. Soc. Exp. Biol. Med. 116: 437.

8. Burkhart, J. M., and J. Jowsey. 1967. Parathyroid and thyroid hormones in the development of immobilization osteoporosis. Endocrinology. 81: 1053.

9. Adams, P., and J. Jowsey. 1967. Effect of calcium on cortisone-induced osteoporosis: a preliminary communication. Endocrinology. 81: 152.

10. Jowsey, J., P. J. Kelly, B. L. Riggs, A. J. Bianco, Jr., D. A. Scholz, and J. Gershon-Cohen. 1965. Quantitative microradiographic studies of normal and osteoporotic bone. J. Bone Joint Surg. A Amer. Vol. 47: 785. 
11. Villanueva, A., H. Frost, L. Ilnicki, B. Frame, R. Smith, and R. Arnstein. 1966. Cortical bone dynamics measured by means of tetracycline labeling in 21 cases of osteoporosis. J. Lab. Clin. Med. 68: 599.

12. Wu, K., S. Jett, and H. M. Frost. 1967. Bone resorption rates in rib in physiological, senile, and postmenopausal osteoporoses. J. Lab. Clin. Med. 69: 810.

13. Heaney, R. P., and G. D. Whedon. 1958. Radiocalcium studies of bone formation rate in human metabolic bone disease. J. Clin. Endocrinol. Metab. 18: 1246.

14. Fraser, R., M. Harrison, and K. Ibbertson. 1960. The rate of calcium turnover in bone: measurement by a tracer test using stable strontium. Quart. J. Med. 29: 85 .

15. Eisenberg, E., and G. S. Gordan. 1961. Skeletal dynamics in man measured by nonradioactive strontium. $J$. Clin. Invest. 40: 1809.

16. Nordin, B. E. C. 1959. Investigation of bone metabolism with ${ }^{17} \mathrm{Ca}-\mathrm{a}$ preliminary report. Proc. Roy. Soc. Med. 52: 351.

17. Melick, R. A. 1966. Calcium-47 kinetics in osteoporosis. Australas. Ann. Med. 15: 318.

18. Trotter, M., G. E. Broman, and R. R. Peterson. 1960. Densities of bones of white and Negro skeletons. J. Bone Joint Surg. A Amer. Vol. 42: 50.

19. Caldwell, R. A. 1962. Observations on the incidence, aetiology, and pathology of senile osteoporosis. J. Clin. Pathol. 15 : 421.

20. Atkinson, P. J. 1965. Changes in resorption spaces in femoral cortical bone with age. J. Pathol. Bacteriol. 89: 173.

21. Meema, H. E., M. L. Bunker, and S. Meema. 1965. Loss of compact bone due to menopause. Obstet. Gynecol. 26: 333 .

22. Nordin, B. E. C., J. MacGregor, and D. A. Smith. 1966. The incidence of osteoporosis in normal women: its relation to age and the menopause. Quart. J. Med 35: 25.

23. Donaldson, I. A., and J. R. Nassim. 1954. The artificial menopause: With particular reference to the occurrence of spinal porosis. Brit. Med. J. 1: 1228.

24. Baylink, D. J., G. P. Vose, W. E. Dotter, and L. M. Hurxthal. 1964. Two new methods for the study of osteoporosis and other metabolic bone disease. II. Vertebral bone densitometry. Lahey Clin. Found. Bull. 13: 217.

25. Smith, R. W., Jr. 1967. Dietary and hormonal factors in bone loss. Fed. Proc. 26: 1737.

26. Henneman, P. H., and S. Wallach. 1957. A review of the prolonged use of estrogens and androgens in postmenopausal and senile osteoporosis. Arch. Intern. Med. 100: 715.

27. Solomon, G. F., W. J. Dickerson, and E. Eisenberg. 1960. Psychologic and osteometabolic responses to sex hormones in elderly osteoporotic women. Geriatrics. 15: 46.

28. Davis, M. E., N. M. Strandjord, and L. H. Lanzl. 1966. Estrogens and the aging process: the detection, prevention, and retardation of osteoporosis. J. Amer. Med. Ass. 196: 219.

29. Meema, H. E., and S. Meema. 1968. Prevention of postmenopausal osteoporosis by hormone treatment of the menopause. Can. Med. Ass. J. 99: 248.

30. Milch, R. A., D. P. Rall, and J. E. Tobie. 1957. Bone localization of the tetracyclines. J. Nat. Cancer Inst. 19: 87.

31. Frost, H. M. 1963. Measurement of human bone formation by means of tetracycline labelling. Can. J. Biochem. Physiol. 41: 31 .
32. Rasmussen, H., and A. Tenenhouse. 1967. Thyrocalcitonin, osteoporosis and osteolysis. Amer. J. Med. 43: 711.

33. Jones, J. D., and W. F. McGuckin. 1964. Complexometric titration of calcium and magnesium by a semiautomated procedure. Clin. Chem. 10: 767.

34. Frings, C. S., R. Rahman, and J. D. Jones. 1966. Automated method for the determination of serum inorganic phosphorus: comparison with manual procedure. Clin. Chim. Acta. 14: 563.

35. Marsh, W. H., B. Fingerhut, and E. Kirsch. 1959. Adaptation of an alkaline phosphatase method for automatic colorimetric analysis. Clin. Chem. 5: 119.

36. Yarbro, C. L., and R. L. Golby. 1958. Complexometric titration of urinary calcium and magnesium. Anal. Chem. 30: 504.

37. Prockop, D. J., and S. Udenfriend. 1960. A specific method for the analysis of hydroxyproline in tissues and urine. Anal. Biochem. 1: 228.

38. Smith, H. W. 1956. Principles of Renal Physiology. Oxford University Press, Inc., New York. 237.

39. Faiman, C., and R. J. Ryan. 1967. Radioimmunoassay for human follicle stimulating hormone. J. Clin. Endocrinol. Metab. 27 : 444.

40. Faiman, C., and R. J. Ryan. 1967. Radioimmunoassay for human luteinizing hormone. Proc. Soc. Exp. Biol. Med. 125: 1130 .

41. Albert, A., E. Rosemberg, G. T. Ross, C. A. Paulsen, and R. J. Ryan. 1968. Report of the National Pituitary Agency collaborative study on the radioimmunoassay of FSH and LH. J. Clin. Endocrinol. Metab. 28: 1214.

42. Albright, F., and E. C. Reifenstein, Jr. 1948. The Parathyroid Glands and Metabolic Bone Disease: Selected Studies. The Williams \& Wilkins Co., Baltimore. 393.

43. Heaney, R. P. 1962. Radiocalcium metabolism in disuse osteoporosis in man. Amer. J. Med.,33: 188.

44. Lafferty, F. W., G. E. Spencer, Jr., and O. H. Pearson. 1964. Effects of androgens, estrogens and high calcium intakes on bone formation and resorption in osteoporosis. Amer. J. Med. 36: 514.

45. Eisenberg, E. 1966. Effects of androgens, estrogens and corticoids on strontium kinetics in man. J. Clin. Endocrinol. Metab. 26: 566.

46. Jowsey, J. 1965. Indirect measurement of bone resorption. J. Clin. Endocrinol. Metab. 25: 1408.

47. Heaney, R. P. 1965. A unified concept of osteoporosis. Amer. J. Med. 39: 877.

48. Jasani, C., B. E. C. Nordin, D. A. Smith, and I. Swanson. 1965. Spinal osteoporosis and the menopause. Proc. Roy. Soc. Med. 58: 441.

49. Jowsey, J., W. Lafferty, and J. Rabinowitz. 1965 Analysis of distribution of $\mathrm{Ca}^{\mathrm{ss}}$ in dog bone by a quantitative autoradiographic method. J. Bone Joint Surg. A Amer. Vol. 47 : 359.

50. Parfitt, A. M. 1965. Changes in serum calcium and phosphorus during stilboestrol treatment of osteoporosis. J. Bone Joint Surg. B Brit. Vol. 47: 137.

51. Young, M. M., C. Jasani, D. A. Smith, and B. E. C. Nordin. 1968. Some effects of ethinyl oestradiol on calcium and phosphorus metabolism in osteoporosis. Clin. Sci. 34: 411.

52. Nassim, J. R., P. D. Saville, and L. Mulligan. 1956. The effect of stilboestrol on urinary phosphate excretion. Clin. Sci. 15: 367 . 
53. Katz, F. H., and A. Kappas. 1968. Influence of estradiol and estriol on urinary excretion of hydroxyproline in man. J. Lab. Clin. Med. 71: 65.

54. Young, M. M., and B. E. C. Nordin. 1967. Effects of natural and artificial menopause on plasma and urinary calcium and phosphorus. Lancet. 2: 118.

55. Gardner, B., W. P. Graham III, G. S. Gordan, H. F. Loken, A. N. Thomas, and J. S. Teal. 1963. Calcium and phosphate metabolism in patients with disseminated breast cancer: effect of androgens and of prednisone. J. Clin. Endocrinol. Metab. 23: 1115.

56. Kroon, D. B. 1958. Effect of parathyroid extract on osteogenic tissue. Acta Morphol. Neer-Scand. 2: 38.

57. Rasmussen, H. 1968. The parathyroids. In Textbook of Endocrinology. R. H. Williams, editor. W. B. Saunders Company, Philadelphia. 4th edition. 847. 